\title{
개발협력 인재 양성과 ODA \\ 생태계 육성 방향 : 학계
}

목 차

I. 서론

II. 연구 동향

III. ODA 생태계와 인재 양성

1. ODA 생태계와 학계

2. 국내 ODA 인재 양성 현황

3. 해외 사례

IV. 개발협력 인재 양성과 ODA 생태계 육성을 위한 학계의 역할

1. 학계의 역할

2. 학계의 운영 프로그램

3. 민 · 관 - 학 협력 방안

V. 결론

참고 문헌

* 본 연구는 2018년 한국국제협력단(KOICA)이 발주한 「KOICA 사업의 국내고용효과 분석 및 효과적인 ODA산업 생태계 육성방안, 연구용역의 일부로 수행된 연구임. 


\section{요 약}

본 연구의 목적은 공적개발원조(Official Development Assistance, ODA) 생태계 의 활성화와 개발협력 인재 양성을 위해 학계의 역할과 운영 방안을 논의하는 것이다. 이를 위해 개발협력의 생태계는 어떻게 구성되며 또 인재 양성을 어떤 방식으로 추진해 야 하는지에 대해 학계 입장에서 역할, 운영 프로그램 및 민.관.학 협력 방안을 모색했다. 또한 $\mathrm{ODA}$ 예산 확대 방침에 맞추어 $\mathrm{ODA}$ 생태계도 활기를 띨 것으로 전망됨에 따라, 대학이나 연구기관 같은 학계는 인재의 공급 기관이자 수요 기관으로서 그 역할이 더욱 중요해지고 있다.

ODA 생태계가 유기적으로 연계되고, 활력을 되찾기 위해서는 개발협력 분야의 인재 가 필요하다. 이를 위해 민관 협력을 통한 학계의 활발한 움직임이 전개되어야 할 것이다. 대학이나 대학원에는 현장에 기반을 둔 교육과정의 개편은 물론 교수진을 보강해야 한다. 아울러 중장기 연구 과제와 사업을 전개해 개발협력 인재의 양성과 활용 면에서 체계적 으로 운영되어야 할 것이다. 


\section{I. 서론}

국제사회는 빈곤 퇴치뿐만 아니라 인권과 민주주의 등 다양한 이슈를 다루고 있다. 그리고

서로 협력해 문제를 해결하는 것을 공통적으로 인식하고 있다. 우리나라도 이러한 추세에 맞추어 그동안 국제사회와의 협력을 확대해 왔다. 어려운 경제 여건 속에서 공적개발원조(Official Development Assistance, 이하 ODA)를 꾸준하게 증액하고 있다. 하지만 국제사회의 시각에 서 보면, 여전히 부족한 것이 현실이다. 국민총소득(Gross National Income, 이하 GNI) 대비 ODA 비중이 개발원조위원회(Development Assistance Committee, 이하 DAC) 회원국 중에서 하위권에 있다는 것이 이를 뒷받침한다.

2018년 우리나라의 ODA는 3조 원 규모인데, 일반 산업의 생태계를 구성하기에는 적은 규모다. 그럼에도 불구하고 지속가능발전목표(Sustainable Development Goals, 이하 SDGs) 달성이라는 국제사회의 요청과 예산의 증대 등을 고려할 때 향후 ODA 생태계는 활성화될 것으로 보인다. 4차 산업혁명, 제도 혁신, SDGs 달성 등 패러다임의 급격한 변화 속에 개발협력 분야에 적합한 맞춤형 생태계의 구축과 생태계 활성화를 위한 인재 수요는 꾸준히 증가할 것이 다. 이는 개발협력의 발전 및 확대의 핵심적인 요소가 된다. 따라서 인재의 양성과 활용에 대한 부분을 차분하게 준비하는 것은 매우 중요하다.

개발협력은 현장 인력의 활동을 중심으로 전개된다. 따라서 현장에서의 활동을 고려할 때, 인재의 역할 그리고 인재의 중요성에 의미를 두고 있다. 이는 사람을 통해 현지에서 다양한 활동이 끊임없이 진행되기 때문이다. 하지만, 현지의 활동을 이해하기란 쉽지도 않고 또 경험하 고 있는 사람도 많지 않다. 이는 국내에서 $\mathrm{ODA}$ 를 전개할 때도 마찬가지다. 다시 말해, ODA 생태계의 속성은 현지와 본부의 유기적인 연계가 있어야 한다. 그러므로 단순한 여행을 통한 경험과 현지에서 '작업’을 한다는 것도 매우 다르다. 이러한 점에서 볼 때, 개발협력 현장에서 필요한 인재를 구한다는 것은 현실적인 한계가 있다. 따라서 개발협력 인재의 양성 및 활용에 대한 구체적인 체계를 마련할 필요가 있다. 즉, 이러한 개발협력 인재를 양성하는 데 있어 그 분야의 활발한 활성화가 선행되어야 한다. 이를 'ODA 생태계’의 활성화라고 일컬을 수 있다. 생태계는 사회조직을 유기적 형태로 보는 측면에서, 구성 요소의 밀접한 관련성을 핵심 요소로 규정하고 있다.

$\mathrm{DAC}$ 회원국의 ODA 규모는 $1,440.2$ 억 달러(2017년 잠정 통계)로, 그 규모가 성장 추세에 있다. 오래 전부터 이 분야에서 주도적인 역할을 한 공여국의 경우, 인재를 활용해 국제사회에서 다양한 역할을 하고 있다. 특히, 대학이나 연구기관 등의 학계는 인력을 양성함과 동시에 전문성 
을 활용하기 위한 체계를 갖추고 있다. 미국의 경우, 학부나 대학원 과정에서 제 3 세계와 관련된 연구는 분야를 막론하고 활발하게 전개되고 있다. 또 영국, 프랑스 및 스페인 등 유럽 국가들은 식민지 학문의 연장선상에서 아프리카 및 아시아에 대한 깊은 연구와 역량을 보유하고 있다. 또한 독일도 마찬가지다. 체계적인 연구와 역량을 갖춰 전문성 활용에 기초해 접근하고 있다. 일본 역시 국제 분야에 대한 전략적 접근은 물론 관련 전문성을 보유한 인재 양성 및 활용에서도 국제대학원이나 관련 학부를 통해 활발하게 활동하고 있다. 그리고 호주나 뉴질랜드 역시 영어 라는 언어의 강점을 살려 컨설팅과 연구 사업을 활발하게 추진하고 있다.

한국 정부는 국제사회에 지속적인 대외원조 예산의 증액을 천명했고, 실제로 2009년 이후에 매년 20 30\% 씩 ODA 예산을 증액하고 있다. 이로써 $\mathrm{DAC}$ 회원국 가운데 증가율이나 속도로 보면 최상의 위치에 있다. 하지만, ODA는 국가의 예산이고 또 국민의 세금으로 운영되고 있기 때문에 보다 효율적인 사용을 요구하고 있다.

한편, 최근에는 일자리 창출과 연계하는 방법도 고려하고 있다.「청년일자리 대책 보고대회 겸 제5차 일자리위원회」(2018. 3. 15.)에서는 '해외 지역전문가 양성'과 관련해 정부의 정책 방향을 발표했다. 그 주요 내용을 살펴보면 다음과 같다. 첫째, 해외 지역의 전문성을 배양하기 위한 수단으로 한국국제협력단(Korea International Cooperation Agency, 이하 KOICA) 등 1 년 이상 장기 해외 봉사단을 확대한다. 둘째, 파견 봉사단에 대한 관리를 내실화하기 위해 현지 봉사단의 관리 인력을 증원한다. 셋째, 해외 근무 경력이 국내외 취업으로 연계될 수 있도 록 지원을 강화한다 등이다. 아직은 인적자원개발의 관점이라기보다는 단기 효과 위주의 정책이 라는 한계가 있지만, 이제부터라도 문제점을 직시하고 또 일자리를 통한 인재 양성으로 방향을 전환했다는 점에서 의의는 있다.

본 연구의 목적은 ODA 생태계의 활성화와 개발협력 인재를 양성하기 위해 학계의 역할과 운영 방안을 논의하는 데 있다. 이를 위해 개발협력의 생태계는 어떻게 구성되며 또 인재 양성을 어떤 방식으로 추진해야 하는지에 대해 학계 입장에서의 역할, 운영 프로그램 및 민·관.학 협력 방안을 모색했다. 구체적인 내용은 개발협력 인재 및 ODA 생태계와 관련된 연구 동향을 탐색하고, 국내외 현황을 살펴보았다. 그리고 ODA 생태계의 활성화와 개발협력 인재를 양성하 기 위한 학계의 역할과 운영 프로그램을 제안했다.

본 연구는 향후 개발협력 분야를 전반적으로 활성화하는 데 기여할 것으로 본다. 


\section{II. 연구 동향}

개발협력 인재의 양성과 관련한 연구 동향은 다음과 같이 정리할 수 있다. 첫째, 개발협력 인력의 양성과 관련된 연구다. 국내 연구에서는 전문 인력에 초점을 둔 연구가 있는데, 전문 인력에 대해서는 유형별로 나누기도 한다. 김광연(1993)의 연구는 개발협력에 국한하지 않고, 국제협력 전문 인력의 양성과 확보를 위해 $\mathrm{KOICA}$ 의 내부 및 외부 인력 pool을 구성하는 것을 제안했다. 이를 통해 중장기 관점에서 전문 인력 양성 방안을 제시한 연구인데, 개발협력 분야의 인재 양성에 대한 선구적 연구로서 의미가 있다. 이 연구를 심화해 $\mathrm{KOICA}$ 내부 전문가 양성 프로그램에 대한 연구도 있다(이태주 : 1998). 이들 두 연구는 우리나라 초기 개발협력 생태계에서 인력 양성의 중요성을 제시한 연구로서 의미가 있다.

또한 장지순(2007)은 개발협력의 전략과 방향으로 연구기관 및 대학 등 전문 기관의 인적 자원 활용, 사전조사의 중요성, 전문성 함양을 위한 전문가의 양성, 국제 네트워크의 강화, 특별 기금을 활용한 재원 확보 등을 제시하기도 했다.

그리고 최민경(2008)은 경제협력개발기구(Organization for Economic Cooperation and Development, 이하 OECD) 개발원조위원회(Development Assistance Committee, 이하 $\mathrm{DAC}$ ) 선진국의 개발 전문가 육성 사례를 통해 $\mathrm{KOICA}$ 사업 수행 전문가의 효율적인 활용 및 역량 강화 방안, 민간 부문(private sector)의 잠재적인 개발 전문가 육성 방안, 준전문가 (junior expert) 및 장래 개발 전문가의 역량 개발 방안, 국제협력 인재 육성 및 연구조사, 정보 발신의 중심 기관인 국제개발협력 종합센터의 구축 제안 등을 제시했다.

또 김철희(2011)는 개발협력 인력 양성 체계의 현황과 문제점, 주요국의 인력 양성 체계에 따른 사례 분석을 통해 개발협력 분야의 인력 양성 체계 구축 방안을 제시했다. 개발협력 인력 양성 체계를 구축하기 위한 기본 방향으로 다양성과 일관성 있는 인력 양성 체계 구축, 개발협력 일원화(분권화 해소)에 부합하는 복·융합형 인력 양성 시스템의 체계화, 개발협력 관련 정보공 유시스템 구축(생성, 가공, 배분, 활용), 생애 연계형 개발협력 인력 양성, 취업·일자리 연계 정책 강화 등을 제시했다.

이와 함께 황혜신·김철회(2015)는 국제개발협력 분야의 전문 인력 양성에 대한 현황 조사, 전문가 심층 면접 등을 통해 전문가의 역량과 필요 인력 양성 방안을 제시했다. 동 연구에서는 전문가 관련 통합 시스템 구축과 유형별 역량 강화 방안을 제시해 전문 인력의 양성은 물론 활용할 수 있도록 했다.1)

1) 동 연구에서는 개발협력과 인재 양성에 대한 연구 동향을 자세하게 다루고 있음. 
둘째, $\mathrm{ODA}$ 사업과 고용과의 관계다. 최근 연구에 따르면, $\mathrm{ODA}$ 사업은 다른 재정지원 사업 과 달리 해외에서도 고용 창출이 가능할 수 있다는 특성이 있다는 점을 제시하고 있다(정진호 외, 2016). 그동안의 고용 효과에 대한 분석은 전형적인 국내 산업의 시장만을 놓고 분석한 경우가 대부분인데, $\mathrm{ODA}$ 는 해외 고용에 대한 부분도 고려한다는 점이 새로운 접근인 셈이다. 이는 $\mathrm{ODA}$ 에서의 고용은 국내 고용뿐만 아니라 해외 진출과도 밀접한 관련이 있다는 것을 보여 준다.

$\mathrm{ODA}$ 를 통한 일자리 창출에 대한 연구에서는 일자리 창출의 의미, $\mathrm{ODA}$ 에서의 일자리 창출 사업의 내용 분석, 청년 일자리 창출에 기여한 효과성 분석 등을 제시하고 있다(국제개발협력학 회 : 2017). 그러나 ODA와 고용과의 관계에 대해서는 아직 많은 연구가 진행되지 않고 있다. 반면, 해외에서는 다양한 사례가 있다. 특히, Max Mendez-Parra와 Dirk Willem te Velde (2017a)은 영국에서의 수출과 관련해 고용을 분석하고 있다. 이 연구에서는 1 달러의 양자 지원 을 통해 0.22 달러의 수출 효과가 있으며, 2014년의 자료를 분석한 결과 59 억 달러의 양자 지원 을 통해 13 억 달러의 수출 효과와 1 만 2 천 개의 일자리를 창출했다는 분석 결과를 제시했다. 이들은 유럽연합(European Union, 이하 EU)을 대상으로 유사한 연구도 진행했다(Max Mendez-Parra·Dirk Willem te Velde : 2017b). 이 연구는 ODA를 통해 수출과 일자리에 대한 계량 분석을 했다는 점에서 의의가 있다.

윤유리·김효신(2017)은 KOICA의 ODA로 인해 얻을 수 있는 국내 고용 효과를 ODA 사업 에 따른 직접적인 고용이 아닌, $\mathrm{ODA}$ 로 발생한 추가적인 수출에 대한 고용 효과를 분석했다. 분석 결과, $\mathrm{KOICA}$ 의 $\mathrm{ODA}$ 는 약 119,500 여 개의 일자리 창출에 기여했고, 이는 전체 고용의 약 $0.51 \%$ 에 해당되며, 수출에 의한 고용 창출을 기준으로 약 $1.95 \%$ 에 달하는 것으로 나타났다. 즉, $\mathrm{KOICA} \mathrm{ODA}$ 가 $1 \%$ 증가 시 수출은 약 $0.04 \%$ 증가하는 것으로 나타났으며, 2015년 기준으로 $\mathrm{KOICA}$ 의 무상원조는 전체 수출의 약 $2.6 \%$ 에 기여한 것으로 볼 수 있다.

셋째, SDGs에서도 언급되었듯이 협력 대상국의 일자리에 대한 부분이다. 이 부분은 본 논문 의 주제와는 별개로 볼 수 있지만, ODA가 현지에 영향을 주는 요소라고 봤을 때 한 번은 고려해야 할 부분이다. 특히, SDGs에서도 이 부분은 더욱 강조되고 있다. SDG 8은 '좋은 일자리와 경제성장'(Decent Job and Economic Growth)을 목표를 정하고, 고용과 창업 등을 통한 발전에 초점을 두고 있다. 저숙련.단순 노동에 머물고 있는 여성과 아동 등 취약 계층을 위한 일자리가 매우 중요하고, 청년 고용에 대한 부분도 같이 고려해야 한다는 것을 지적하고 있다. 특히, 국제노동기구(International Labor Organization, 이하 ILO)는 2009년 경제위기 이후 고용 활성화를 위한 정책을 발표했다. 'Global Jobs Pact'라는 이 정책은 경제 회복과 
좋은 일자리 기회 회복 사이의 시간 격차를 줄이기 위한 정책 결정의 기반을 제공하기 위한 목적으로 제시되었다(ILO, 2009).

아울러 2012년에 Post 새천년개발목표(Millennium Development Goals, 이하 MDGs)의 개념을 제시했는데, MDGs 이후는 일자리(job)와 생활(livlihood)에 모든 것을 집중해야 한다 고 했다. 당시 사무총장이었던 Guy Ryder는 일자리 창출(Job creation)이 글로벌 발전의 최우선이라고 했고, 좋은 일자리(decent job)는 가난을 없애는 가장 좋은 방법이라고 했다. 즉, ILO는 개발협력 과정에서 일자리 창출(job creation)과 사회 보호(social protection)를 최우선 해결 과제로 삼아야 한다는 점을 강조했다(ILO, 2012). 이러한 내용은 SDGs에 그대로 적용되었다.

\section{제 I 장}

또한 유엔개발계획(United Nations Development Programme, 이하 UNDP)도 경제위기 이후에 이를 극복을 위해서는 일자리가 중요하다는 것을 강조하고 있는데, 환경과 관련된 일자 리의 중요성을 제시하고 있다. 특히, 공공 접근으로 빈곤층을 위한 녹색 일자리를 제안했다. 그러면서 다양성 보존, 저하된 토지의 복원, 침식 방지 및 수원 보존 등의 공공 일자리에 대한 지원 등을 통해 새로운 일자리 창출의 가능성에 주목하고 있다(UNDP, 2009).

아울러 개발도상국의 중소기업을 대상으로, 금융·기술혁신·인력 양성·수출 분야 등에 대한 지원 방안에 대한 연구도 있다(이시욱 외, 2016). 이 연구에서는 동 분야에 대한 한국의 경험을 기반으로 개발도상국과의 협력을 모색했고, 실질적으로 개발도상국 고용과 경제에 영향을 줄 수 있는 중소기업에 대한 지원이 SDGs에 부합하다는 것을 제시했다. 


\section{ODA 생태계와 인재 양성}

\section{ODA 생태계와 학계}

$\mathrm{ODA}$ 생태계는 참여자와 다양한 이해관계자로 구성되었다. 먼저, 정부기관으로는 정책을 집행하는 각종 부처가 있으며, 정책 집행에 대해 시민사회의 목소리를 대변하는 민간단체가 있다. 또한 사업을 발주하는 유상 및 무상 주관기관 등이 있는데, 이러한 ODA 사업 발주에 대한 사업 시행자로서 기업, 공공기관, 학계, 협회 및 민간단체 등이 참여한다. 기업체는 실제 사업에 참여하거나 민관 협력을 기반으로 한 사회공헌 활동의 일환으로 참여하는 기업 등 다양 하게 분포하고 있다.

$\mathrm{ODA}$ 사업에 참여하는 기업 중 해외에서 발주가 진행되는 경우, 대기업이 참여하는 경우가 많다. 하지만, 국내에서 발주되는 경우에는 대기업의 참여 제한으로 인해 중소기업만이 참여하 고 있다. 다만, 민관협력 사업에는 대기업은 물론 중소기업도 참여한다. 최근에는 관련 부처와 밀접하게 연계된 협회에서 활동하는 경우가 많아지고 있다.

\section{〈그림 1〉 ODA 생태계의 이해관계자}

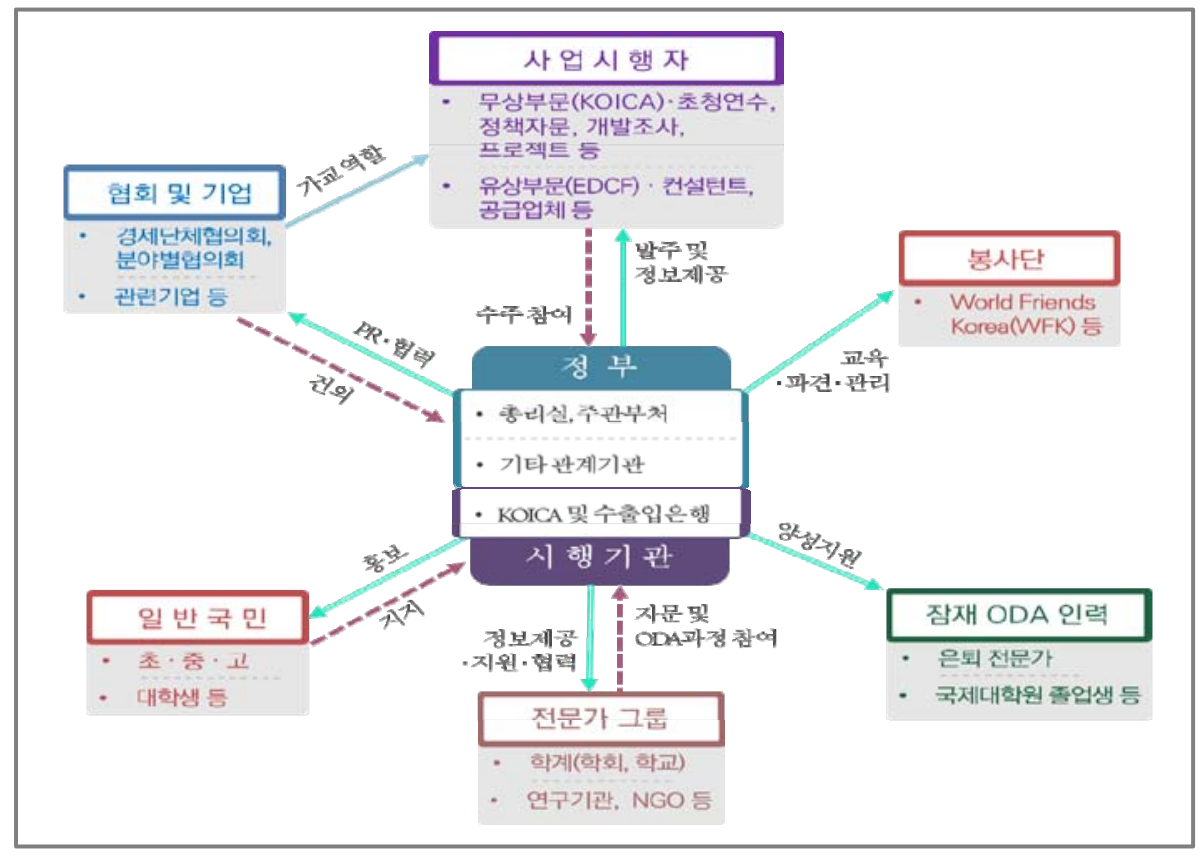

출처: 저자 작성 
$\mathrm{ODA}$ 생태계에서 학계는 전문가 그룹으로 볼 수 있다. 전문가 그룹의 대표 기관으로는 학회 와 대학이 있다. 개발협력과 관련된 학회는 국제개발협력학회가 가장 활발하게 활동하고 있으 며, 개발정책학회도 있다. 그리고 일반 분야의 학회는 분과위원회를 두거나 간헐적으로 $\mathrm{ODA}$ 를 주제로 학술포럼을 개최하기도 한다. 전문가 그룹으로서의 대학은 교수나 연구원 등이 사업 참여자로서 역할을 수행하기도 하지만, 개발협력 인재를 양성하는 역할도 수행하고 있다. 학부 차원에서는 KOICA와 협력해 국제개발협력이해증진 사업을 실시하고 있거나, 드물게는 개발 협력 관련 학과를 개설하는 대학도 있다. 대학원 과정은 개발협력 전공과정을 운영하거나 교육, 보건, 농업과 같은 개발협력의 주제에 맞춘 과정을 운영하는 경우도 있다.

제I장

\section{2. 국내 $\mathrm{ODA}$ 인재 양성 현황}

\section{1) 수요 측면 : 정부 주요기관 및 공공기관 현황}

개발협력 인재의 양성 현황을 수요와 공급 측면에서 분석하는 경우는 많지 않지만, 수요 현황은 다음과 같은 측면에서 분석할 수 있다.2) 첫째, 우리나라 전체 $\mathrm{ODA}$ 의 예산 현황과 이와 관련된 국내 시장 규모를 통해 파악할 수 있다. 앞에서도 제시했지만, ODA 예산 규모가 확대될수록 수요는 증가할 것으로 전망된다. 둘째, 정부 주요부처, 유상 및 무상원조 기관인 대외경제협력기금(Economic Development Cooperation Fund, 이하 EDCF)과 KOICA의 사업을 통한 현황 분석 및 해당 기관의 인력 현황 등을 통해서도 파악할 수 있다. 셋째, 민간단체 의 사업 규모 및 인력 현황 등을 통해 알 수 있고, $\mathrm{DAC}$ 통계를 통해 국제시장의 규모 및 주요 국제기구의 인력 현황 등의 자료를 기반으로 잠재적 시장을 파악할 수 있다. 민간 기업의 수요는 현실적으로 추정하기 어려운 구조를 가지고 있지만, 민간 기업은 사회적 공헌 활동 차원과 해외 진출이라는 측면에서 인력을 활용하는 것으로 추정할 수 있다. 다만, ODA 생태계에서 민간의 수요는 가장 큰 잠재 시장 중의 하나이므로, 민간에서 수요를 창출할 수 있는 제도나 정책의 보완이 필요하다. 3 )

우리나라의 $\mathrm{ODA}$ 규모는 점진적으로 증가하고 있고, 부처 및 관계 기관에서도 사업을 확대하는 추세다. 일부 부서는 개발협력 관련 부서를 새롭게 설치하고 있으며, 대부분의 기관은 국제 관련 부서에 해당 기능을 추가하기도 한다. 이러한 추세를 고려할 때, 개발협력에 대한 수요는 점차 증가할 것으로 보인다. 또한 연구나 평가를 수행했던 개발컨설팅사들도 실제로 사업에 참여하면서 인력을 채용하고 있으며, 개발 비정부기구(Non-Governmental Organization, 이하 NGO)에

2) 본 내용은 장지순·정봉근(2013)의 자료를 참조해 정리했음.

3) 이에 대해서는 전용일·장지순(2018) 자료 참조. 
서도 관련 전공자를 대상으로 채용 방식을 선회하고 있다. 이처럼 변화하는 국내외 환경을 고려할 때, 향후 역량 있는 '개발 전문가'및 '전문 인력'에 대한 수요는 관련 기관들은 물론 민간 기업에서 도 증가할 것으로 예상된다. 이는 ODA 생태계의 활성화와 밀접하게 연계되어 있다.

<표 1>은 정부 주요기관의 인력 현황을 보여 준다. 2015년 비해 약 1.5 배 정도의 인력이 증원되었다. 이는 $\mathrm{ODA}$ 예산 확대와 밀접하다.

〈표 1〉 정부 주요기관 인력 현황

\begin{tabular}{|c|c|c|c|c|}
\hline 정부부처 및 기관 & 직원 수(2012) & 예산 & 직원 수(2017) & 예산 \\
\hline 개발협력 담당 국무조정실 직원 & 13 & 52만 달러 & 14 & 66만 달러 \\
\hline 개발협력 담당 외교통상부 직원 & 33 & & 33 & 3억 1백4십5만 달러 \\
\hline $\begin{array}{c}\text { KOICA 총 인력 } \\
\text { 한국 근무 } \\
\text { (본부 } \cdot \text { 현장) } \\
\text { 해외 사무소 현지 인력 }\end{array}$ & $\begin{array}{c}422 \\
294 \\
(209 / 85) \\
128\end{array}$ & $\begin{array}{l}\text { 6억 1천6백만 } \\
\text { 달러 }\end{array}$ & $\begin{array}{c}514 \\
345 \\
(258 / 87) \\
169\end{array}$ & $\begin{array}{l}\text { 6억 3천5십만 } \\
\text { 달러 }\end{array}$ \\
\hline 개발협력 담당 기획재정부 직원 & 23 & & 41 & $\begin{array}{c}\text { 1억 2천4백2십만 } \\
\text { 달러 }\end{array}$ \\
\hline $\begin{array}{c}\text { EDCF 총 인력 } \\
\text { 한국 근무 } \\
\text { (본부 } \cdot \text { 현장) } \\
\text { 해외 사무소 현지 인력 }\end{array}$ & $\begin{array}{c}94 \\
92 \\
(83 / 11) \\
0\end{array}$ & $\begin{array}{l}\text { 10억 5천만 } \\
\text { 달러 }\end{array}$ & $\begin{array}{c}147 \\
137 \\
(111 / 26) \\
10\end{array}$ & 9억 8천7백1만 달러 \\
\hline 총계 & 585 & & 749 & \\
\hline
\end{tabular}

출처: 경제개발협력기구 (2018)

가장 활발하게 활동하는 분야는 봉사단 및 전문가 파견 분야다. 인력 파견 분야는 수요와 공급 측면에 모두 해당된다. 관심 있는 인력이 지원하기 때문에 수요가 될 수 있고, 파견 활동이 끝나는 시점에는 지역 또는 분야 전문가로 공급되기 때문이다. 이는 국내 및 국제기구의 경우로 나눌 수 있는데, 국내는 대부분 KOICA를 통해 이루어지고 있다. 현재 World Friends Korea 라는 브랜드로 4 개 부처, 6 개 유형으로 파견하고 있는데, 2015년 기준으로 총 96개국에 55,763 명이 파견되었다(한국국제협력단, 2016). 결과적으로, 2015년에만 4,814명이 파견되어 있는 상태다. 아시아 지역이 $76.2 \%$ 로 나타나 압도적으로 많고, 아프리카 및 중남미 순으로 높게 나타났다. ${ }^{4)}$ 분야별로는 교육(54.8\%), 보건(13.4\%), 농림수산(13.3\%), 산업에너지(9.1\%), 공 공행정( $8.9 \%)$ 등이다.

4) 자세한 내용은 한국국제협력단(2016) 「한눈에 읽는 2015년 World Friends Korea 주요통계」참조. 
$\mathrm{KOICA}$ 에서는 2010년부터 자체 봉사단 사후관리 차원에서 국내외 소재 대학 및 대학원에 진학하는 봉사단을 대상으로 학비의 75\%를 지원해 주는 사업을 전개하고 있다. 2015년 기준으 로 제6기를 지원했는데, 248 명이 혜택을 받았다. 이들은 잠재적 전문 인력으로서 의미가 있는 숫자다. 하지만, 전체 인원에 비해 혜택을 받은 숫자는 적은 편이어서 향후 확대가 필요하다. 이와는 별도로 중장기 자문단이 파견되는데, $\mathrm{KOICA}$ 의 경우에는 39 개국 536 명이 파견되었다 (2010 2015 합계). 이들은 봉사단과 달리 공공행정(50\%), 농림수산(18.5\%), 산업에너지 $(11 \%)$ 등의 분야에 파견되었다. 또한 정보통신 및 산업 분야의 자문단에서 정보통신산업진흥원 (National IT Industry Promotion Agency, 이하 NIPA) 자문단의 경우, 동 기간에 43개국 491명이 파견되었다.

제I장

한편, $\mathrm{KOICA}$ 와 한국수출입은행에서는 전문가 풀(pool)을 운영하고 있다. $\mathrm{KOICA}$ 는 14 개 분야 에 852 명을, 한국수출입은행은 15 개 분야에 826 개 법인과 2,057 명의 개인 전문가를 등록해 운영하 고 있다(황혜신 외 2015). 이러한 숫자가 현재 파악할 수 있는 수요와 밀접한 연관성이 있다.5)

현재 국책연구기관 및 공공기관에서는 해당 주제나 분야에 맞춘 연구와 사업을 추진하고 있다. 가장 활발하게 전개하고 있는 기관은 한국개발연구원이다. 기획재정부의 지식공유사업 (Knowedge Sharing Program, KSP) 주관 기관으로서 국제개발협력센터를 설치해 3실 6개 팀을 운영하고 있다. 또한 한국농촌경제연구원은 1 개 센터에 2 개 팀을 운영하고 있으며, 보건. 농업·교육·정보통신·행정·여성 등을 다루는 다른 기관의 대부분은 관련 센터나 팀을 조직해 해당 분야의 연구와 사업을 추진하고 있다.

공공기관은 본격적인 사업을 추진하는 곳이 많다. 한국정보화진흥원에서는 글로벌협력단을 두고, 3 개의 팀을 구성해 자체 사업과 외주 용역 사업을 진행한다. 또 한국농어촌공사는 해외사 업본부를 설치하고, 2 처 7 부를 두어 비교적 대규모의 사업을 진행하고 있다. 도로, 교통, 철도, 고용, 정보통신, 보건 등 다른 분야도 마찬가지로 국제 관련 부서를 두고 사업을 추진하고 있다. 이렇듯, 연구 기관이나 공공 기관에서의 수요도 점차 증가하고 있는 추세라고 보면 된다.

국제기구에 파견되는 경우도 많지는 않지만, 인턴십·JPO(Junior Professional Officer). YPP(Young Professionals Programme)·UNV(The United Nations Volunteers Programme) 등의 프로그램이 있다. 국내외 교육과정을 이수한 자들이 주로 지원하기 때문에 수요처로서 의미를 지닌다. 아울러 이러한 프로그램은 개발협력 분야의 인재를 양성하는 데도 활용된다. 특히, 청년층이 개발협력 전문가로 양성되는 과정에서 매우 중요한 경험과 지식을 함양할 수

5) 다만, 여기에는 기업이나 시민단체 등 민간 기관에서의 수요는 조사 방법의 한계 때문에 제외했지만, 수요가 가장 많을 것으로 추정할 수 있음. 
있도록 한다. 더욱이 국제기구 진출의 토대가 되는 주요한 통로가 된다. 그래서 상대적으로 인기가 높지만, 선발 인원이 제한된다는 제약도 따른다. 이 분야는 해당 기구와의 협의를 통해 인원이 조정되고, 관련 예산이 수반되므로 매우 전략적인 접근이 있어야 한다. 다만, 해당 분야 의 인재 양성 과정이 매우 중요하므로, 적극적인 협의와 예산 지원을 통해 선발 인원을 확대할 필요가 있다. 이와는 별도로 선진국을 대상으로 한 글로벌 인턴 및 해외봉사 사업 등도 있는데, 이 역시 글로벌 인식 제고 측면에서 잠재 인력으로 간주될 수 있으므로 기회 제공 측면에서 확대될 필요가 있다.

\section{2) 공급 측면: 대학 및 대학원}

개발협력 인재를 가장 많이 공급하고 있는 곳이 대학과 대학원이다.6) 그러나 개발협력 관련 전공을 다루고 있는 곳은 전체 대학과 대학원 수에 비하면 많지 않다. 개발협력에 대한 이해 증진을 위해 학부 학생을 대상으로 과목을 개설하는 경우도 있지만, 고등교육 단계에서의 이해 제고나 전문성 함양을 꾀하기에는 턱없이 부족하다.

따라서 $\mathrm{KOICA}$ 는 국제개발협력 사업에 대한 국민의 이해 및 참여도 제고, 세계시민의식 함양과 국제사회에서 한국의 기여 및 위상을 강화하고자 2009년부터 '국제개발협력이해증진 사업’을 도입했다. 2010년부터 2017년까지 총 259개교에 25,810명이 참여했다.

\section{〈표 2〉 국제개발협력이해증진 사업 현황}

\begin{tabular}{c|c|c|c}
\hline 구분 & 대상 학교 수 & 수강 학생 수 & 예산7)(백만 원) \\
\hline 2009 & 17 & - & - \\
\hline 2010 & 29 & 1,740 & - \\
\hline 2011 & 33 & 2,926 & - \\
\hline 2012 & 37 & 3,787 & - \\
\hline 2013 & 43 & 5,431 & 17,454 \\
\hline 2014 & 30 & 3,331 & 20,426 \\
\hline 2015 & 30 & 2,773 & 20,735 \\
\hline 2016 & 30 & 3,023 & 27,648 \\
\hline 2017 & 27 & 2,799 & - \\
\hline 계 & 259 & 25,810 & - \\
\hline
\end{tabular}

출처: KOICA 홈페이지 (http://www.koica.go.kr/) (접속일: 2018.09.20.) 내용을 참고해 저자가 재구성

6) 본 연구에서는 실태조사를 반영하지 않고, 해당학교 홈페이지 및 대학교육협의회의 자료를 활용했으므로, 실제 현황과 다소 차이가 있음.

7) 예산자료는 KOICA 홈페이지 자료를 활용. 
대학교육협의회에 따르면(2017년 기준), 국제대학원 또는 대학원 과정에 관련 분야 184 개 과정이 개설되어 있다. 여기에는 국제통상, 국제경영, 국제정치, 국제법, 국제학, 국제관계학, 국제지역학 등이 대부분이다. 또 국제개발학, 국제협력학, 국제보건학, 국제문화학, 국제평가거버넌스학, 환경국제보건학, 국제교육개발협력학, 국제사회문화교육, 국제농업기술학, 국제도 시개발프로그램 등의 전공도 있다. 전공당 인원은 20 명 내외다.

이러한 양성 과정은 개발협력에 특화하기보다 국제학 분야 전반에 걸쳐 있다. 또한 현장과의 접목을 통한 교육보다는 국제경제와 국제정치 등 기본 이론에 치중하고 있었으며, 개발도상국 현장을 접할 수 있는 기회는 많지 않았다. 특히, 국제대학원의 경우에는 설립 당시의 목적이 국제통상 전문 인력 양성에 있으므로, 교수진도 동 분야의 교수진으로 구성되어 있다. 따라서 엄밀한 의미에서 보면, 국제협력이나 개발 분야와는 거리가 있다. 개발 분야가 융합적·학제적 성격을 띠고 있다 보니 이에 맞추어 전공 교수나 과정을 개선할 필요가 있고, 이와 함께 관련 연구를 확대하고, 정보도 공유할 수 있는 체제를 구축할 필요도 있다.

이들 과정 중에서 주요 대학의 대학원 과정을 살펴보면 다음과 같다. ${ }^{3)}$ 한국개발연구원 부설 국제정책대학원에서는 개발정책 전공 과정(Master of Development Policy: MDP)이 운영 되고 있다. 이 과정에 국내 학생은 물론 외국 학생들도 참여한다. 박사과정은 입학 후 1 년 동안 전일제 수업(One-year Residency Requirement)을 통해 9개 과목(27학점)을 이수한 후 전공 종합시험에 합격하는 절차가 있다. 주요 과목은 시장과 공공정책분석(Analysis of Market and Public Policy), 개발정책입문(Introduction to Development Policy), 연구방 법론(Introduction to Research Methods), 원조와 개발(Aid and Development), 반부패와 거버넌스(Anti-Corruption Reform and Good Governance), 개발과 사회변화(Development and Social Change in Korea), 개발원조와 NGO의 역할(Development Assistance and Role of NGOs), 기업가 정신과 개발(Entrepreneurship and Development) 등 다양하게 구성되었다. 개발정책 과정을 이끌어 가는 교수진은 대부분 경제학 전공자들로 구성되어 있어, 다양성과 융합성 등을 보완하기 위해 초빙교수제도를 활용하고 있다.

또한 경희대학교 국제대학원 국제개발협력학 과정에는 개발협력 전공의 석사 및 박사과정이 있있다. 또 석사과정은 국제개발협력의 이해, 개발경제학, 응용경제학 및 프로젝트 사이클 관리 등을 이수하도록 규정하고 있다. 선택 과목에는 프로젝트 모니터링과 평가, 비즈니스 컨설팅, 프로젝트 모니터링과 평가, 국제개발협력 전략, 컨설팅 기법 실무 등 실제 현장에서 직접 활용이 가능한 과목 위주로 구성되었다. 이는 실무형 국제개발컨설턴트 양성을 목적으로 한 국제개발컨

8) 각 전공은 홈페이지 자료를 참조해 정리했으므로 실제와는 차이가 있을 수 있음. 
설팅 석사과정으로, 기존의 국제개발협력 전공과 달리 개발학과 경영학의 융합 프로그램을 표방하며 모듈식로 운영되고 있다. 이 과정 역시 경제학 전공자들이 교수진으로 구성되었고 또 $\mathrm{KOICA}$, 아시아개발은행(Asian Development Bank, 이하 $\mathrm{ADB}$ ), 국책연구기관에서 활 동한 경력이 있는 분을 초빙교수로 활용하고 있다.

아울러 이화여자대학교 국제대학원 국제학 전공은 2008 년에 교육부의 국제협력 전공 특성화 전공으로 시작한 후, $\mathrm{KOICA}$ 와 협력해 개발협력 전공을 운영하고 있다. 개발협력 전공 과정은 필수 과정으로서 연구방법론과 개발협력의 이론과 실제 등은 물론 저명강사 특강, 인턴십, 작문 및 발표 워크숍, 진로 관리 등을 공통으로 이수하고 있다. 교수진은 경제학이나 사회학 등의 전공자들로 구성되어 있고, $\mathrm{KOICA}$ 과정을 위한 전담 교수와 초빙교수를 활용하고 있었다.

\section{3) 공급 측면 : 연구기관, 학술 및 시민단체}

대학과 대학원 같은 교육기관 이외에도 개발협력 생태계 차원에서 인재를 양성하거나 활용하 고 있는 곳으로는 연구기관, 학술단체 및 시민단체가 있다. 하지만, 이 역시 일부 시민단체를 제외하고 전문적으로 양성하는 차원보다는 인력을 활용하는 차원에서 검토할 수 있다. 가장 활발하게 활동하는 학회로는 한국국제개발협력학회, 한국개발정책학회가 있으며, 타 학회에서 는 분과위원회를 두거나 ODA를 주제로 한 포럼을 개최하기도 한다. 그러나 학회 차원에서의 양성 기능을 두고 있는 곳은 없다. 한국국제개발협력학회에서는 관련 기관을 대상으로 포럼 개최 및 세미나 비용을 지원하기도 한다. 연구기관은 주제에 맞추어 국제협력 사업과 연구조사 를 병행하고 있다. 또한 양자 협력 관계는 물론 다자 협력에서의 연구조사 사업을 진행하는 경우도 많고, ODA뿐만 아니라 양해각서(Memorandum of Understanding, 이하 MOU)를 통해 연구를 위한 국제교류 협력 차원에서 반드시 진행하기도 한다. 연구재단의 경우, 글로벌협 력 사업을 진행하는 교육부와 과학기술정보통신부의 ODA 사업을 전담해서 수행한다. 특히, 교육부의 국제협력선도대학 사업은 실제 투입되는 인력을 고려할 때 양성의 기능도 있으며, 과학기술정보통신부의 개도국과학기술지원 사업은 기관 간 협력 사업과 적정기술거점센터 사 업으로 진행된다. 이들 사업은 해당 전공의 석·박사과정 학생이 직접 참여함으로써 개발도상국 에 대한 이해를 높이고, 추후 해당 분야에 진출하는 등의 역할을 한다. 실제로 적정과학기술거점 센터(5개국)를 통해 정·하수, 농업 관련 기술 개발(4건), 사업화(7만 달러 매출, 48 명 취업), 인력 양성(86명)을 실시했다. 또한 정보접근센터(52개)를 운영해 1.8 만 명의 개발도상국 현지인 들에게 PC·인터넷 접속을 지원했으며, 1,046 명이 센터 내 IT-소프트웨어 교육을 받고 취업에 성공했다. 정보통신기술(Information and Communications Technologies, 이하 ICT) 정책 컨설팅(연간 12 건) 및 초청 연수(연간 250명) 등을 실시한 결과, 현지 법·제도·기술 개선(13건) 
및 해외 진출(6건, 709만 달러) 등의 성과도 거두었다.9)

민간단체의 경우, 국제개발협력민간단체협의회(Korea NGO Council for Overseas Development Cooperation, 이하 KCOC)에서는 KOICA의 위탁을 받아 '국제개발협력교육 (일반인 대상)'과 '민간단체 역량강화교육(민간단체 실무자 대상)'을 실시하고 있다. 전자는 일반 시민들을 대상으로 실시하는데, 국제개발협력 기본교육과 국제개발협력교육 강사양성훈 련, 교원직무연수, 개발교육, 세계시민교육 아이디어 공모전 등 다양한 교육 프로그램 및 국제개 발협력 인식 프로그램을 운영하고 있다. 후자는 민간단체 역량 프로그램으로, 해외 사업 수행관 리와 긴급구호 및 인도적 지원에 대한 교육으로 나뉜다.10)

제I장

\section{3. 해외 시례11)}

\section{1) 영국}

영국은 $\mathrm{DAC}$ 회원국 중 체계, 예산 등의 분야에서 가장 모범적인 국가 중 하나다. 이는 독립된 부서를 두어 운영하고 있으며, DAC의 권고 사항인 GNI 대비 $0.7 \%$ 의 예산을 배분하고 있기 때문이다. 다시 말해, 개발협력 주관 기관인 국제개발부((Department for International Development, 이하 DFID)에서 발주되는 사업의 $80 \%$ 를 컨설팅 기업이 수주하고 있다. 그러 므로 민간 분야의 개발협력 생태계가 매우 활발한 편이다. 이렇듯, 민간 분야 개발협력 사업의 발주 비율이 대체적으로 높아서 공공 부문뿐만 아니라 민간 분야에서 동 분야의 고용을 창출하 는 데 기여한 것으로 보인다. 특히, SDGs를 달성하기 위한 협력 대상국 거버넌스 개발, 경제 및 사회 발전부터 인프라 및 자원 개발도 포함되었고, 개발협력 분야는 물론 연관된 다른 다양한 분야에서 양질의 일자리를 창출하고 있다. 아울러 기업들은 ‘글로벌 기업의 사회적 책임(Global $\mathrm{CSR})^{\prime}$ 이라는 측면에서도 활발하게 활동하고 있는데, 이 역시 생태계 활성화에 도움을 주고 있다.

또한 영국은 해외 진출과 개발협력을 밀접하게 연계하고 있다는 특징이 있다. 특히, 무역투자 청(United Kingdom Trade \& Investment, 이하 UKTI)를 활용해 민간 기업들을 위한 지원 프로그램을 제공하고 있다. 'Aid Funded Business Service'라는 제도를 활용해 UKTI 소속

9) 과학기술정보통신부 보도자료(2017. 12. 4.) 참조. (www.korea.kr/common/download.do?fileId=185775966\& tblKey=GMN : 접속일: 2018. 9. 20.)

10) 자세한 내용은 장지순·정봉근(2015) 및 국제개발협력 민간단체협의회의 홈페이지 자료 참조.

11) 본 사례는 황혜신 외(2015) 및 한국국제개발협력학회(2017)를 참조해 관련 기관의 홈페이지 내용을 다시 정리했음. 
민간 기업들이 영국이 발주한 ODA 사업에 참여할 수 있는 기회를 제공한다. 이는 '버밍햄 상공회의소'와 'British Expertise International(BEI)'에서 동 사업을 총괄하고 있다. 한편, $\mathrm{BEI}$ 는 약 50 년 정도의 역사를 가지고 있으며, 인프라 분야에 대한 지원뿐만 아니라 국제시장에 서의 비즈니스를 확보하는 것을 지원하는 곳으로서 200 여 개의 회원사와 밀접하게 연계해 운영하고 있다. 특히, 특별한 분야의 전문가들이 포함되어 있어서 중소 규모의 기업들이 사업을 확대하는 데 직접적인 도움을 주기도 한다. ${ }^{12)}$

주요 기관을 소개하면 아래와 같다.

\section{〈표 3〉 영국의 컨설팅 기관}

\begin{tabular}{|c|c|}
\hline 기업 & 주요 활동 내역 \\
\hline $\begin{array}{l}\text { Adam Smith } \\
\text { International }\end{array}$ & $\begin{array}{l}\text { - } 1992 \text { 년에 설립된 민간 국제개발협력 컨설팅 기업 } \\
\text { - 주요 사업은 국제개발협력 컨설팅 서비스 제공이며, DFID 사업을 수주해 프로젝트를 } \\
\text { 진행함. } \\
\text { - 사업 분야는 거버넌스, 경제 발전, 사회 발전, 인적자원 관리, 인프라 개발, 천연자원 } \\
\text { 관리까지 포괄하고 있음. } \\
\text { - 다양한 분야에서 국제개발협력 프로젝트와 컨설팅 서비스를 제공해 국제개발협력 전문 } \\
\text { 가뿐만 아니라 섹터별 전문가들을 위한 양질의 일자리를 창출하고 있음. 특히, DFID의 } \\
\text { 사업을 수주해 수행하기 때문에 대외 원조의 양적 확대를 통해 국내외 국제개발협력 } \\
\text { 분야의 일자리 창출에 많은 기여를 하고 있음. } \\
\text { - 고용 방식은 프로젝트별로 컨설턴트와 계약을 체결해 사업을 수행함. }\end{array}$ \\
\hline $\begin{array}{l}\text { Gatsby } \\
\text { Foundation }\end{array}$ & $\begin{array}{l}\text { - 국제개발협력 분야에서 CSR 사업을 수행 } \\
\text { - 영국의 민간 국제개발협력 컨설팅 기업으로서 기업의 사회적 책임(Corporate Social } \\
\text { Responsibility, 이하 CSR) 분야에 대한 서비스를 중점적으로 제공함. } \\
\text { - 영국의 주요 지원 국가인 아프리카에서 사업을 수행하고 있으며, 현지 컨설턴트들과 } \\
\text { 계약을 체결해 사업을 수행하는 구조임. } \\
\text { - DFID의 사업보다 기업의 CSR에 대한 서비스를 제공해 민간 부문에서 국제개발협력 } \\
\text { 혹은 관련 분야의 일자리를 창출하고 있음. }\end{array}$ \\
\hline
\end{tabular}

출처: 국제개발협력학회 (2017) 내용을 참고해 저자가 재구성

2) 독일

독일도 ODA 예산이 많은 국가 중 하나로, 예산 규모 측면에서 ODA 생태계 육성에 활발한 편이다. 연방경제개발협력부(The Federal Ministry for Economic Cooperation and Development, 이하 BMZ)를 중심으로 관련 정책을 체계적으로 추진하고 있으며, 국제협력공 사(Deutsche Gesellschaft für Internationale Zusammenarbeit, 이하 GIZ)에서 대외원조

12) https://www.britishexpertise.org/ (접속일 : 2018. 9. 20.) 참조.

60 | 국제개발협력 
실무를 총괄하고 있다. 또한 컨설팅 분야의 활성화를 위한 지원과 관련 프로그램을 기본적으로 운영한다. 독일재건은행(The Kreditanstalt für Wiederaufbau, 이하 KfW)도 관련 분야에 대한 지원을 하고 있다. 기본적으로 컨설팅 분야에서 사업의 발굴과 진행을 하기 때문에, 이 분야에 대한 지원을 확대해 자국 사업은 물론 국제시장에서의 경쟁력을 갖출 수 있도록 하고 있다. 다시 말해, 개발협력 프로젝트의 활성화를 위해 개발협력컨설팅 산업의 생태계를 활성화 하고 있는 것이다. 개발협력 사업의 절차를 고려할 때, 연구와 조사와 같은 컨설팅 분야의 확대 는 전체 사업의 확대에 영향을 주기 때문에 독일의 이러한 정책 방향은 의미가 있다.

독일에서 운영되고 있는 영프로페셔널(young professional, 이하 $\mathrm{YP}$ )은 한국의 제도와 유사하다. $\mathrm{YP}$ 는 대학(원)생들이 인턴 프로그램에 참여해 국제개발협력 업무를 배울 수 있는 기회를 제공한다. 또한 분야별 전문가를 양성하기 위한 '농업경제발전 세미나(Seminar für Ländliche Entwicklung, 이하 SLE)'를 운영한다.13) SLE는 영어로 Center for Rural Development인데, 1962년에 시작된 농업 분야 전문 세미나로서 현재까지 농업 분야 전문가들 을 800 명 이상 육성했다. 특히, 농업 전공자뿐만 아니라 사회과학.공학.법학 등 다양한 분야의 학생들이 참여하며, 이 과정을 수료한 학생들은 농업개발·정책·제도 등의 전문성을 활용해 국제 개발협력 컨설팅 서비스 기업에서 활동하게 된다.

또한 해외 진출 기관과 연계해 인재들이 협력 대상국 현장으로 진출할 수 있도록 지원하는 프로그램이 있다. 독일연방고용기구(International Placement Services, 이하 ZAV), 국제이 민개발센터(The Centre for International Migration and Development, 이하 CIM), 독일 개발서비스(The German Development Service, 이하 DED) 등이 이에 해당한다. 파견 분야는 직업훈련, 환경, 공공행정, 보건의료, 농촌개발 등 수요가 많은 부분이다. ODA와 자국 기업의 진출을 철저하게 연계함으로써 시너지 효과를 거둘 수 있도록 한다. 스리랑카에 대한 독일의 직업기술교육훈련(Technical and Vocational Education and Training, 이하 TVET) 분야의 지원은 이러한 지원의 좋은 사례다. 스리랑카에 진출하려는 독일 기업의 직종이나 업종에 맞추어 TVET에 대한 지원을 하고, 졸업생들을 취업시킴으로써 일석이조의 효과를 거두고 있다.

독일 내 주요 컨설팅 기관은 아래와 같다.

13) https://www.sle-berlin.de/index.php/en/ (접속일: 2018. 9. 20.) 
〈표 4〉 독일의 컨설팅 기관

\begin{tabular}{|c|c|}
\hline 기업 & 주요 활동 내역 \\
\hline GOPA & $\begin{array}{l}\text { - GOPA 컨설팅 그룹은 1969년에 설립된 사설 국제개발컨설팅 기관임. } \\
\text { - 사업 분야는 } \boldsymbol{\Delta} \text { 국제개발협력 프로젝트 기획 · 운영, } \mathbf{\Delta} \text { 국제개발협력 프로젝트 관련 } \\
\text { 교육 프로그램 운영, 시티타 국제개발협력 사업 } \\
\text { - 주요 사업 파트너는 유럽연합(EU), 독일기술협력공사(GTZ), 독일재건은행그룹(KfW) 밀 } \\
\text { 레니엄 챌린치 코퍼레이션(Millennium Challenge Cooperation, MCC)과 세계은행 } \\
\text { (World Bank) 등이며, } 133 \text { 개 국가, 3,000개 이상의 프로젝트를 수행 } \\
\text { - GOPA 컨설팅 그룹은 ‘국제개발협력, 농업, 금융, 지역, 경제 전문가 등’ 다양한 전문가 } \\
\text { 풀을 운영하고 있음. }\end{array}$ \\
\hline $\begin{array}{l}\text { Icon Institute } \\
\mathrm{GmbH} \& \text { Co.KG }\end{array}$ & $\begin{array}{l}\text { - 1976년 쾰른에 설립된 국제개발협력컨설팅 회사 } \\
\text { - 사업 분야는 } \boldsymbol{\Delta} \text { 개발도상국 민간섹터 개발, } \boldsymbol{\Delta} \text { 국제개발협력 컨설팅 서비스, } \boldsymbol{\Delta} \text { 식량안 } \\
\text { 보 관련 프로젝트 수행 } \\
\text { - 직원 수는 } 180 \text { 명 이상으로 GOPA 컨설팅 그룹에 비해 적은 편이나, 재정 현황이 지속적 } \\
\text { 으로 증가하는 점을 고려하면 국제개발협력 컨설팅 업계에서 양질의 일자리를 꾸준히 } \\
\text { 창출할 수 있을 것으로 판단됨. }\end{array}$ \\
\hline
\end{tabular}

출처: 국제개발협력학회 (2017) 내용을 참고해 저자가 재구성

(3) 일본

일본은 지식산업 육성과 진흥을 위해 1964년에 ‘해외컨설팅기업협회’를 통상산업성에 설립했 다. 설립 당시 해외 시장 진출과 개발을 전문적으로 수행할 수 있는 민간 컨설팅 기업 육성에 초점을 두었는데, 이것이 민간 차원의 국제개발협력의 시작이고 또 컨설팅의 활성화라고 볼 수 있다. 그리고 1991년부터 주요 대학 내 국제대학원을 설립해 국제개발협력 전공자들을 배출 했다. 나고야대학교(Nagoya University), 고베대학교(Kobe University), 히로시마대학교 (Hiroshima University), 사이타마대학교(Saitama University) 등이 여기에 해당한다. 이들 은 ‘영어 강의', '현장중심 교육과정', ‘사회·경제 발전에 특화된 프로그램' 등을 통해 국제개발협 력의 전문성을 확장했다.

2011년부터는 국제개발협력 컨설팅 산업 활성화를 위한 정책을 도입했다. 이는 기업이 국제 개발협력 분야에 참여하며 해외 시장에 진출하도록 기반을 마련하는 것이다.

일본국제협력기구(Japan International Cooperation Agency, 이하 JICA)는 ODA 사업 에 민간 기업들의 참여 확대와 기술 협력의 비중을 높임으로써 국제개발협력 전문가뿐만 아니라 기술 전문가들의 참여도 촉진시켰다. 또한 JICA는 'Framework for Supporting Japanese SMEs in Overseas Business'를 개편해 중소기업이 ODA를 통해 해외 시장에 진출할 수 있도록 했다.14) 아울러 국제개발협력 사업의 범위를 공공 부문에 제한하지 않고, 민간 분야의 
적극적인 참여가 가능한 구조를 형성했다. 이를 통해 민간 국제개발협력 컨설팅을 활성화하기 위한 정책을 도입했다. 또한 중소기업이 ODA 사업에 참여할 수 있는 기회를 제공해 개발협력 컨설팅 시장뿐만 아니라 민간 분야에서 국제개발협력 및 기술협력 전문가의 수요가 창출될 수 있도록 했다.

주요 사례는 다음과 같다.

〈표 5〉일본의 컨설팅 기관

\begin{tabular}{c|c}
\hline 기업 & \multicolumn{1}{c}{ 주요 활동 내역 } \\
\hline $\begin{array}{c}\text { (주)일본개발 } \\
\text { 서비스(JDS) }\end{array}$ & $\begin{array}{l}\text { - JDS는 일본 ODA 사업 수행 및 번역 서비스를 제공 } \\
\text { - 기관 퇴직자 혹은 기업 퇴직자 등과 계약을 맞고 업무를 수행하지만, 대학원 졸업생들도 } \\
\text { JDS에서 프로젝트를 수행할 수 있는 기회를 제공함. }\end{array}$ \\
\hline IC-NET & $\begin{array}{l}\text { - IC-NET은 세계은ㅎㅐㅐ, ADB와 같은 다자개발은행들(MDB)과 사업을 수행 } \\
\text { - 전체 인력은 100명이며, JICA의 ODA 업무도 함께 수행 }\end{array}$ \\
\hline Saitama & $\begin{array}{l}\text { - 일본 의료기기 업체인 Saitama는 JICA의 ODA 사업에 참여한 중소기업으로서 국제의료 } \\
\text { 분야 및 기술협력 분야에 참여 }\end{array}$ \\
$\begin{array}{l}\text { Saitama는 베트남에 신생아 황달 진단 의료기기를 수출했는데, 그 결과 베트남 시장의 } \\
\text { 확보와 의료기기 시장을 확대 }\end{array}$
\end{tabular}

출처: 국제개발협력학회 (2017) 내용을 참고해 저자가 재구성

(4) 호주

호주개발원조청(AusAid)은 국제개발협력 분야의 전문 인력 양성과 양성된 인력들을 수용하 기 위한 국제개발협력 산업 생태계를 구축했다. 전문 인력을 양성하기 위해 '개발전문가 육성 프로그램'을 활용해 대학에서 '국제개발협력학'을 전공한 대학생 및 대학원생들을 위한 취업 활동 프로그램들을 제공했다. 동 프로그램에 지원한 학생들은 호주개발원조청에서 9 개월간 근무할 수 있는 기회가 주어진다. 특히, 학생들은 '현장 실습 훈련(On the Job Training, OJT)'을 기반으로 순환 근무를 통해 개발협력 사업에 대한 이해도를 높이도록 했다. 또한 현장 전문성을 높이기 위한 세미나 및 특별 교육 프로그램을 이수하도록 했다. 이 과정을 통해 학생들은 사무 업무를 체계적으로 수행할 수 있는 '행정 전문가'와 개발도상국 현장 중심의 '현장 전문가'로서 역량을 개발해 장기적으로 진로와 커리어 개발에 활용할 수 있도록 했다.

14) 2012년 3월에 개편했는데, 이에 따라 2016년 3월에 1,649개의 제안서를 받아서 296개의 사업을 실행하기도 했음. 민간 분야, 특히 중소기업을 포함한 민간 분야와의 협력은 2015 년 2 월에 내각에 의해 승인된 개발협력헌장에도 반영된 부분임. 
개발협력 생태계를 구축하기 위해 국제개발협력 컨설팅 산업을 활성화할 수 있는 전담 기관 으로 '호주무역위원회(AusTrade)'를 선정했다. 즉, '국제개발협력 컨설팅'을 개발협력 사업뿐 만 아니라 기업의 시장 진출 그리고 국제조달 시장 진출을 장려하기 위한 것으로 활용하고 있다. 이를 위해 호주무역위원회는 민간 국제개발협력 컨설팅 기업들에게 세계은행(World Bank), $\mathrm{ADB}$, 국제연합(United Nations, 이하 $\mathrm{UN}$ ) 등에서 제공하는 국제기구 원조조달시장 진출 자문서비스를 제공하고 있다. 또한 호주무역위원회의 해외 사무소들을 통해 해외 기업들을 위한 입찰지원서비스까지 제공하고 있다. 아울러 호주개발원조청도 민간 국제개발협력 컨설팅 기업들이 적극적으로 사업을 수주할 수 있는 기회를 제공해 프로젝트 수주 역량을 강화하도록 하고 있다. 그 결과, 호주의 컨설팅 기업들의 국내 사업 수주율은 $85 \%, \mathrm{ADB}$ 사업 수주율은 $10 \%$ 이상에 달한다. 이로 인해 개발협력 전문 인력이 행정·사무 전문가뿐만 아니라 전문 컨설 턴트로 양성될 수 있는 생태계가 구축되었다.

뿐만 아니라, 정부는 국제기구 발주 수주율을 높이기 위해 세계은행과 협의해 '호주 컨설턴트 신탁기금'을 운용하고 있다. 실제로, 호주 출신 컨설턴트들은 위 신탁기금을 통해 세계은행 프로젝트에 참여할 수 있다. 또한 국제금융공사(International Finance Corporation, 이하 IFC)에서도 위 기금을 활용해 국제금융 분야에서도 참여하고 있다. 한편, 호주의 국제개발NGO 들도 호주 개발원조청의 사업들을 수주하고 있다. 비록 사업 규모는 $7 \%$ 내외에 불과해 민간 국제개발협력 컨설팅에 비해 적은 편이나, 협력 대상국 현지에서 파트너십을 구축하기 위한 중요한 역할을 하고 있다. 그리고 국제개발NGO들과 다양한 사업을 운영해 국제개발협력의 전문성을 지닌 청년들이 현장으로 진출할 수 있는 기회를 제공하고 있다. 


\section{IV. 개발협력 인재 양성과 ODA 생태계 육성을 위한 학계의 역할}

\section{1. 학계의 역할}

제I장

개

발

협

력

이

슈

국제사회에서는 빈곤 퇴치, 민주주의와 인권, 성 평등과 환경 등 다양한 이슈가 논의되고 있다. 학계에서는 다양한 분야의 전문성을 보유하고 있으므로, 이러한 이슈에 대한 심도 있는 연구와 조사를 할 수 있다. 이를 통해 관련 분야의 전문성을 함양하는 것은 물론 인재 양성에도 기여할 수 있게 된다. 우선, 17 개의 SDGs 목표를 달성하기 위한 개발협력의 전개 방향에 대한 연구를 통해 세부목표 달성 방안을 제시할 수 있도록 한다. 여기에는 적정 기술을 활용한 과학기술 분야에 대한 연구 내용도 충분히 포함된다. 둘째, 개발과 같이 고민해야 할 민주주의와 인권에 대한 연계 방안도 연구가 필요한 시점이다. 셋째, 성 평등에 대한 이슈는 범 분야 이슈로 서 개발협력의 과정에서 반드시 고려해야 할 내용이고 또 포함해야 되므로 이에 대한 연구도 필요하다. 넷째, 환경은 기후변화와 관련된 부분은 물론 현지 지역민의 삶과 밀접한 관련이 있다. 특히, 이 부분은 사전 연구에서 충분하게 다루어야 할 부분이고, 관련 사업 이후에도 지속적인 관리가 필요한 부분이므로 연구와 조사가 필요하다. 이러한 부분이 학계에서 싱크탱크 (Think Tank)로서 지속적인 연구와 조사를 통해 관련 이슈를 주도하도록 해야 한다.

\section{2) 지속적인 투자와 연구를 통한 인재의 양성}

대학, 연구기관 및 학회 등의 학계는 개발협력에 필요한 연구와 조사를 할 수 있는 조건을 갖추고 있다. 글로벌 사회에서 발생하는 다양한 이슈에 대한 연구를 추진하기 위해서는 지속적 인 투자도 있어야 한다. 특히, 개발협력 분야의 인재를 양성하고 또 이를 활용하기 위해서는 더욱 그러하다. 그래서 투자의 방법에 대해 다양한 접근이 필요하다. 우선, 대학의 경우에는 글로벌 이슈에 대한 연구와 개발에 대한 투자를 유도한다. 또한 인문사회과학뿐만 아니라 적정 기술의 적용이나 ICT 활용 등 이공계에서도 할 수 있는 분야가 많다. 이러한 곳에 대한 투자를 할 수 있도록 예산을 배분한다. 그리고 관련 분야의 전공 개설 및 교육과정 개발 등을 통해 인재를 양성한다. 


\section{3) 민간과의 교류 및 협력 확대}

ODA 생태계는 민간과의 교류와 협력을 통해 활성화된다. 그래서 학계에서 할 수 있는 부분 은 해당 분야에 대한 연구와 개발을 통해 인재를 양성하고, 성과물을 민간과 공유하도록 하는 것이다. 따라서 $\mathrm{ODA}$ 와 연계해 새로운 형태의 산학연계 프로그램을 구성할 필요가 있다. 이를 위해 민간과의 교류협력이 필수적이다. 따라서 기존에 진행되고 있는 산학협력이나 민간과의 교류협력 분야에 개발협력 분야도 포함해 확대할 수 있는 방법을 모색해야 한다. 즉, 새로운 track을 설정해 지속적인 개발을 통해 진행할 수 있도록 해야 한다. 예를 들어, 기업은 관련 기금을 마련하고, 대학은 연구와 개발을 통해 이를 공유한다. 또한 인턴십이나 현장 훈련 (OJT)을 적극 도입하고, 경험이 많은 기업체 인사들을 초청강사로 활용하는 등 인적 교류도 활용한다. 또 기업은 물론 시민단체 등과 같이 할 수 있는 분야에 대한 협력 프로그램이 필요하다. 지역, 주제, 분야 등을 놓고 여기에 적용할 수 있는 기술의 적용이나 정보의 활용에 대한 것을 고려할 수 있도록 한다. 학계에서 가장 잘할 수 있는 부분이 해당 분야에 대한 심화이고, 특히 광범위한 개발협력 분야에서 해당 부분에 대한 깊이 있는 연구를 통해 성과를 공유할 수 있도록 한다.

\section{2. 학계의 운영 프로그램}

\section{1) 융합과 현장의 조화를 둔 교육과정의 재편}

$\mathrm{ODA}$ 생태계를 활성화하기 위한 학계의 가장 중요한 기능은 개발협력 인재의 양성이다. 개발협력은 다루는 분야의 특성을 고려할 때, 학제적 접근과 융합적 접근이 필요하다. 아울러 현지의 다양한 특징도 고려해야 하며, 이러한 점을 고려한 교육과정의 개편이 필요하다. 따라서 초.중등 학생을 대상으로 한 교육과정, 학부과정을 위한 과정 그리고 본격적인 전문 과정을 위한 대학원 과정 등이 체계적으로 연계될 수 있도록 해야 한다. 일부 대학에서 교양 과목으로 운영되고 있는 '국제개발협력의 이해'를 확대할 필요가 있으며, 개별 대학의 특성에 따라 필수 교양 과목으로 검토할 필요도 있다. 특히, 대학원 과정의 운영을 위해서는 현장 경험을 충분히 습득할 수 있도록 해야 하고, 과정 운영을 위한 교수진의 보완도 시급하다. 이와 함께 이론을 습득할 수 있도록 할 뿐만 아니라 실제 현장 연구도 시행할 수 있도록 교육과정을 구성하고, 거기에 부합한 외부 인력도 충원해야 한다. 또 대학원 과정에서라도 현장을 충분히 익힐 수 있는 기회를 제공하고, 풍부한 현장 및 사업 경험을 갖춘 교수를 확보할 수 있어야 할 것이다. 


\section{2) 이론과 실무를 아우르는 통합 전문가 풀(pool)의 운영}

각 기관별로 운영되고 있는 전문가 풀(pool)을 ODA 생태계 활성화 차원에서 통합·운영할 수 있도록 한다. 전문가 pool 등록에 필요한 항목을 해당 분야의 학위나 논문 위주에서 벗어나 실제 경험 위주로 개편해 지역성 및 분야의 전문성 등도 가미하도록 한다. 아울러 현지에 거주하 고 있는 전문가 그룹에 대한 관리도 같이할 수 있도록 한다. 즉, 개발협력에 대한 관점을 국내 거주 전문가에서 벗어나 현지 거주 인재까지 확대해야 한다. 이와 함께 전문가 등급에 대한 개편도 검토할 필요가 있다. 표준화된 전문가의 등급을 현실화하고, 참여할 수 있는 기회를 넓혀야 한다. 경험이 풍부한 전문가는 senior로 하고, 새롭게 참여하는 단계의 전문가는 junior 로 하는 것도 방법이다. 이러한 pool의 학계에도 동일하게 적용해 활용할 수 있도록 한다. 교수나 연구원으로서 대학원 과정이나, 연구 및 개발 사업의 참여할 수 있도록 한다.

\section{제 I 장}

\section{3) 전문 분야별 네트워크 활성화를 위한 포럼 운영}

개발협력 분야에서 가장 활발한 활동을 하고 있는 분야를 선정하고, 각 분야별 전문 포럼을 운영하도록 한다. 관련 학회나 대학 그리고 공공기관 등이 주축이 되어 운영하거나, 아예 새로운 포럼을 설립해 운영하는 것도 방법이다. 예를 들어, 교육개발협력포럼·농업개발협력포럼·보건 개발협력포럼 등을 운영하고, 관련된 연구자나 전문가 그룹이 참여할 수 있도록 한다. 포럼은 전문가를 위한 프로그램은 물론 초보자를 위한 교육 프로그램도 운영할 수 있다. 주제를 중심으 로 지역별·국가별 소모임을 활성화하고, 관련 연구나 사업을 추진하는 것도 방법이다. 이러한 포럼을 통해 전문가의 네트워크도 마련할 수 있고, 해당 분야별 지역의 현지 전문가와 교류협력 을 할 수도 있다.

\section{3. 민 · 관 · 학 협력 방안}

\section{1) 분이별·지역별 ODA 정보 플랫폼 구축}

개발협력은 다양한 분야를 다양한 지역에서 활동하는 것으로, 관련 정보를 공유하는 것이 중요하다. 따라서 민관 협력 차원의 협력을 학계와 연계하도록 플랫폼을 마련함으로써 시너지 효과를 거둘 수 있다. 정보의 내용과 범위는 기초조사부터 심층분석 보고서까지 활용할 수 있도록 한다. 이러한 플랫폼은 회원 등록을 통해 구성하고, 구성원들 사이의 정보 공유가 효율적 으로 이루어질 수 있도록 한다. 적어도 어떤 분야의 사업을 어디에서 할 경우, 관련 정보를 한눈에 확인할 수 있도록 하는 것이 중요하다. 여기에는 관련 분야의 전문가 네트워크도 같이 
공유할 수도 있다.

\section{2) 다양한 협력 프로그램의 활성화}

민·관.학이 협력할 수 있는 프로그램을 활성화할 필요가 있다. 우선, 해외 진출을 위한 협력 프로그램을 마련해 운영하는 것이다. 선진 공여국을 대상으로 한 협력은 삼각협력 차원으로 접근하고, 협력 대상국은 해외 진출 차원에서 협력 프로그램을 운영한다. 예를 들어, 특정 지역 이나 국가로 진출을 희망하는 기업체는 학계와 협력 프로그램을 운영해 상호 시너지 효과를 거둘 수 있도록 한다. 즉, 학계에서는 관련 연구 및 조사를 시행하고, 민간 기관은 기초조사 자료를 토대로 진출 전략을 마련한다. 이후 지속적인 방안을 마련해 현지에 안착할 수 있도록 하고, 아울러 협력 대상국의 시장 형성에 기여할 수 있도록 한다. 동시에 현지 지역 주민과의 협력에 대해서 시민단체와의 협력도 같이 진행할 수 있다. 이를 위한 비용이나 협력은 정부 차원에서 지원함으로써 3자가 협력할 수 있도록 한다. 특히 해외 사례에서도 보듯이 해외 진출 에 대해서는 대한무역투자진흥공사(Korea Trade-Investment Promotion Agency, 이하 KOTRA)와 같은 기구와 연계하는 방안도 검토할 수 있다.

\section{3) 연구 및 조사를 위한 기금 조성}

$\mathrm{ODA}$ 생태계를 활성화하는 데 가장 중요한 것은 관련 분야의 예산 확보다. 정부 예산을 확보하는 것은 한계가 있으므로, 민·관.학이 협력해 기금을 마련하여 활용하는 것도 방법이다. 초기 조사비용은 정부가 지원하고, 본격적인 협력을 위한 비용은 기업이 마련해 학계의 인적 자원을 투입하도록 하는 것이다. 연구 및 개발 비용을 위한 기금은 정부 차원의 신탁기금, 기업 차원의 해외개발기금 등으로 구성할 수 있다. 이러한 자금을 학계에서 활용함으로써 대학원 과정을 풍부하게 운영할 수 있게 된다. 특정 목적을 위한 기금으로도 지정할 수도 있고, 일반적 인 목적으로 활용할 수 있다. 중요한 것은, 관련 예산은 학계를 활성화하는 데 기여하며, 이는 결국 $\mathrm{ODA}$ 생태계를 활성화하게 된다. 


\section{V. 결론}

정부는 국제사회의 문제 해결을 도모하고, 국제사회에서의 수요와 요청 확대에 따라 ODA에 대한 지원을 확대할 계획이다. 사업의 개발뿐만 아니라 확대되는 ODA 예산을 개발협력의 인재 양성과 연계할 경우, 효과적인 측면에서 이상적인 방안이 될 수 있다. 해외 주요 공여국의 사례처럼, 현지 연구나 조사에 대한 자금 지원, 대학원 및 학부 과정에 대한 지원 등을 통해 전문성을 함양하고 또 인재를 양성할 수 있도록 해야 한다.

지금이라도 연구와 조사 분야의 관련 예산과 사업을 확대하는 것이 가장 시급한 과제 중

하나일 수 있다. 시행 기관의 자체 인력에 대한 역량 개발은 물론 관련 이해관계자, 특히 대학이 나 대학원과의 협력을 통한 전문성을 함양하기 위한 특정 예산은 지금 당장 시행해야 할 것이 다. 협력 대상국에 대한 사업을 확대하는 것도 좋지만, 내실을 기하고 또 전문성을 확보할 수 있도록 인재 양성에 보다 많은 예산을 활용해야 할 시점이다. 개발협력의 현장에서는 활동하 는 인재가 매우 중요한 역할을 담당하기 때문이다. 이러한 인재는 한국과 현장을 밀접하게 연계하는 네트워크의 선상에 있으므로 개발협력의 인재를 양성하고 활용하는 것은 아주 중요 한 과제가 된다.

이런 측면에서 $\mathrm{ODA}$ 생태계는 공공기관, 민간단체, 기업, 학계 등의 국내적인 요소는 물론 협력 대상국, 수혜자, 국제기구 등의 외부적인 요소를 모두 고려할 수 있다. 일부에서는 하나의 새로운 산업 분야로 인식해 산업 활성화 측면에서 고려해야 한다고 하지만, 예산이 3 조 원에 불과한 시점에서는 산업 생태계로 하는 데 한계가 있다. 이는 예산이 적어도 30 조 원 정도가 될 때, 생태계 구축이 가능할 것이다.

그러므로 향후 국제 정세를 고려할 때, $\mathrm{ODA}$ 분야의 확대는 정부가 추진해야 할 지향점으로 서 여야를 초월해 심도 있게 고려해야 될 것이다. 아울러 이를 위해서는 대국민 인식 제고에도 노력해야 한다. ODA 생태계의 활성화와 개발협력의 인재 양성은 해외 진출의 기회 확보는 물론 양질의 일자리 창출에도 기여할 수 있다는 것을 인식할 필요가 있다. 따라서 글로벌 정세를 기회로 삼아 해외로 진출할 수 있는 전략을 마련하는 게 시급한 실정이다. 해외 진출의 방향을 선진국은 물론 협력 대상국을 포함한 개발도상국으로 확대해 설정하는 것이 국제사회에 기여하 는 방법이다. 


\section{참고 문헌}

국제개발협력학회. 2017. 『공적개발원조(ODA)를 통한 지속가능한 일자리 창출방안: 청 년일자리 창출을 중심으로』. 세종: 기획조정실.

김광연. 1993. 『국제협력 전문인력 양성 및 확보방안』. 성남: 한국국제협력단.

김철희. 2011. 『국제개발협력 인력양성 체계구축 방안』. 서울: 대외경제정책연구원. 김형주. 2017. “국제개발협력분야의 글로벌 중장년 인재양성사업." 『글로벌리포트(The

HRD Review)』제 93-6호: 82-87.

윤유리·김효신. 2017. 『KOICA 무상원조의 국내 수출 및 고용에 미치는 영향에 관한

연구』. 성남: 한국국제협력단.

이시욱·최석준·최용석. 2016. 『개도국 중소기업 육성을 위한 분야별 $\mathrm{ODA}$ 지원 전략』.

세종: 산업연구원.

이정욱. 2017. “국제개발협력분야의 청년 인재 양성 사업." 『글로벌리포트(The HRD

Revie)W』 제 91-6호: 72-77.

이태주. 1998. 『국제협력 전문인력 양성방안: 내부전문가 양성프로그램을 중심으로』.

성남: 한국국제협력단.

장지순. 2007. “교육 서비스 분야의 국제개발협력에 관한 연구." 『고용능력개발연구』

10-3: 159-180.

장지순·정봉근. 2013.『한국의 개발협력 전문인력 양성체제 현황 및 발전방안』. 세종: 교육부.

전용일·장지순. 2018. ${ }^{\circledR} \mathrm{ODA}$ 사업 및 해외인턴십프로그램과 해외취업사업간 연계방안 연구』. 울산: 한국산업인력공단.

정진호·강창희·이태희. 2016. 『ODA 분야 고용영향 자체 평가 개선방안 연구』. 세종: 한국노동연구원.

최민경. 2008. 『국제개발협력 전문인력 육성 및 활용 방안에 관한 연구』. 성남: 한국국제 협력단.

한국국제협력단. 2016. 『한눈에 읽는 2015년 World Friends Korea 주요통계』. 성남: 한국국제협력단.

황혜신.김철회. 2015. 『국제개발협력관련 전문가 양성 및 활용 제고방안』. 서울: 한국행 정연구원.

Mendez-Parra, M. and te Velde, D.W. 2017. "The effects of aid on EU 
employment and trade: an econometric investigation." London: Overseas Development Institute (ODI).

Mendez-Parra, M. and te Velde, D.W. 2017. "Aid, exports and employment in the UK." London: Overseas Development Institute (ODI).

ILO. 2009. "Recovering from the crisis: A Global Jobs Pact," adopted by the International Labour Conference at its Ninety-eighth Session on 19 June, 2009, Geneva.

---. 2012. "Jobs and livelihoods at the heart of the post-2015 development agenda." ILO concept note \#1 for the post-2015 development agenda.

Geneva: International Labour Organisation (ILO).

경제협력개발기구(OECD). 2018. 『OECD 개발협력 동료검토 Peer Reviews 대한민 국 2018』. 대한민국 정부 역.

UNDP. 2009. "Green Jobs for the Poor: A Public Employment Approach.” New York: United Nations Development Programme (UNDP).

World Bank. 2013. "Innovative Finance for Development Solutions: Initiatives of the World Bank Group.” Washington, D.C.: World Bank.

과학기술정보통신부 보도자료(2017. 12. 4.)(www.korea.kr/common/download.do? fileId=185775966\&tblKey=GMN : (접속일: 2018.09.20.).

British Expertise 홈페이지: https://www.britishexpertise.org/ (접속일: 2018.09. 20.).

The Centre for Rural Development 홈페이지: https://www.sle-berlin.de/index. php/en/ (접속일: 2018.09.20.). 